\title{
EVALUATION OF ANTIBACTERIAL EFFECT OF DIODE LASER 980 NM, TRIPLE ANTIBIOTIC PAST, AND CALCIUM HYDROXIDE ON ENTEROCOCCUS FAECALIS BIOFILM
}

\author{
Maram Farouk Obeid* and Mona Saad Nour**
}

\begin{abstract}
Aim: The purpose of this study is to evaluate the anti-biofilm capacity of Diode laser $980 \mathrm{~nm}$, triple antibiotic mixture and calcium hydroxide.

Methods: Eighty five single-rooted teeth with mature apices were prepared using Protaper Universal rotary nickel titanium system till size \# F4 then contaminated with E.faecalis. Irrigation done using $2.5 \%$ sodium hypochlorite followed by $17 \%$ EDTA. Samples were divided into 4 groups $(n=20)$ according to the irrigant activation method. Laser group,TAP group, $\mathrm{Ca}(\mathrm{OH})_{2}$ group and the control group. Residual bacteria were plated onto Brain Heart Infusion media and determined as colony-forming units (CFU mL-1). Data were analyzed using one way ANOVA followed by performance of Tukey post hoc tests. Significance was set at $\mathrm{p}<0.05$.
\end{abstract}

Results: There was a statistically significant reduction in the mean numbers of colony-forming units among all groups. However, none of the activation methods was able to kill E. faecalis biofilm completely. The Laser group behaved most effectively among all groups.

Conclusion: The adjunctive use of $980 \mathrm{~nm}$ laser is an effective method for bacterial reduction after chemo-mechanical instrumentation of the root canal.

KEYWORDS: Diode laser, TAP, antibiofilm activity.

\section{INTRODUCTION}

Microorganisms found in the infected root canal space are colonizing either as free-floating planktonic cells or attached to each other or to the root canal walls to form biofilms ${ }^{(1)}$. Though planktonic microorganisms can be eradicated by different methods, the elimination of biofilm bacteria from the root canal remains a foremost $\operatorname{task}^{(2)}$.

A biofilm is a community of microorganisms embedded in a matrix of extracellular polymeric substance and attached to a solid surface. It has been believed that within this community the biofilm bacteria have different phenotypes, with different

* Lecturer of Endodontics, Department of Endodontics, Faculty of Dentistry, Ain Shams University.

** Lecturer of Medical Microbiology and Immunology, Department of Medical Microbiology and Immunology Faculty of Medicine- Ain Shams University 
characteristics, than do the same bacteria in their planktonic state. Notable among these differences is the increased resistance to antimicrobial agents ${ }^{(3)}$. Since the bacteria in the necrotic root canal grow frequently in biofilm forms, the success of endodontic treatment will depend on the effective elimination of such biofilms ${ }^{(4)}$.

Facultative gram-positive Enterococcus faecalis is one of the most resistant bacteria discovered in infected root canals, especially in cases with persistent apical periodontitis forming intraradicular biofilms ${ }^{(5)}$.Numerous researches have described their low susceptibility to irrigant solutions ${ }^{(6)}$ and to intracanal medicaments such as calcium hydroxide ${ }^{(7,8,9)}$.

Consequently,effortstoeradicatemicroorganisms could link with achieving effective disinfection. Placement of intracanal medicaments such as calcium hydroxide is frequentlysuggested as it has high $\mathrm{pH}$ that alters the bacterial lipopolysaccharides in the cell wall ${ }^{(13)}$. However, it has been shown that this high $\mathrm{pH}$ is not maintained ${ }^{(14)}$. Furthermore, the increase in $\mathrm{pH}$, can enhance the bacterial attachment to collagen fibers of dentine thus protecting them from the disinfection processes $^{(15)}$.Also, it can decreasethe strength of dentine, even with short span use ${ }^{(16)}$ and it has lowability to penetrate dentinal tubules ${ }^{(17)}$

Antibiotics are used as an adjunct to endodontic treatment but itsineffectiveness in systemic route of administration has led to the intracanal applicationto increase its efficacy [18]. Hoshino et al in $1996^{(19)}$ suggested sterilizing infected root canals by topical use of mixture of ciprofloxacin, metronidazole and minocycline. After that, several studies reported the antimicrobial efficacy of this mixture against the pathogens commonly found inside the root canal system including E.faecalis ${ }^{(20,21)}$.

Recently, disinfection of root canals using Diode Laser has received focus as an alternate antibacterial disinfection protocol for drug-resistant microorganisms ${ }^{(22)}$. Diode lasers emitting at $980 \mathrm{~nm}$ transmit energy through thin flexible fibers that are compatible with the dimensions and curved shapes of root canals. The poweroutput of these lasers ranges from 0.5 to $7 \mathrm{~W}$ and is delivered in two operating modes: continuous wave and pulsed mode. The use of modern laser technology has the great help in reaching areas that are not accessible ${ }^{(23)}$. However, very few studies have examined theefficacy of Diode laser in total eradication of intracanal biofilms, and literature needs furtherinvestigations. Hence, this study was undertaken to compare the antibacterial efficacy of diode laser, triple antibiotic mixture, and calcium hydroxide against intraradicular E.faecalisbiofilm.

\section{MATERIALS AND METHODS}

\section{Sample preparation:}

After approval of the local Ethics committee, eighty five single-rooted teeth with mature apices extracted for periodontal reasons, and free from wear facets or apical resorption, were collected from 4555 year old patients attending the outpatient clinic at the Oral Surgery Department, Faculty of Dentistry, Ain Shams University, Cairo, Egypt and stored in $0.9 \%$ physiological saline at room temperature. The patients were informed about the use of their teeth for scientific purposes.

The teeth were decoronated using a safe sided diamond disc (NTI diamond disc, Axis Dental, USA) mounted on a high-speed contra-angle with water coolant and roots standardized to a length of $10 \mathrm{~mm}$.

All samples were prepared with Protaper Universal rotary nickel titanium system (Dentsply Maillefer, Ballaigues, Switzerland) till \#F4 6\%. The root canals were irrigated with $3 \mathrm{ml}$ of $2.5 \% \mathrm{NaOCl}$ at each change of file followed by $17 \%$ EDTA solution for 1 minute for smear layer removal; and, later rinsed with saline and dried using paper points. The roots were then waterproofed externally using cyanoacrylate and all apical foramina were sealed with composite resin. Finally, the roots were steam autoclaved at $134^{\circ} \mathrm{C}$ for 15 minutes. 


\section{Cultivation of E. Faecalis Biofilm}

A clinical reference isolate of E.faecalis from the Microbiology Laboratory (Microbiology Department, Faculty of Medicine, Ain Shams University, Egypt) was cultured on brain-heart infusion agar (BHI) (Land Bridge Technology Co, Ltd, Beijing, China) (BHI) and incubated anaerobically at $37^{\circ} \mathrm{C}$ for $24 \mathrm{hr}$. A single colony was collected and suspended in sterile BHI broth at $37^{\circ} \mathrm{C}$. The root canals were placed into $1.5-\mathrm{mL}$ Eppendorf tubes with $1 \mathrm{~mL}$ BHI broth containing $10^{8}$ colony-forming units $(\mathrm{CFU}) / \mathrm{mL}$ E. faecalis and then incubated anaerobically at $37^{\circ} \mathrm{C}$ for 3 weeks. The sterile BHI broth was refreshed every other day to ensure bacteria viability.Five specimens were randomly selected and examined by SEM to ensure the presence of E. faecalis biofilm ${ }^{(24)}$.

\section{Classification of Samples}

Eighty contaminated roots were randomly divided into 4 groups $(n=20)$ according to the disinfection protocol as follow

\section{$\mathrm{Ca}(\mathrm{OH})_{2}$ group}

Calcium hydroxide and iodoform paste (Metapex ${ }^{\circledR}$, Meta Biomed Co., Ltd, Korea) was introduced into canals. The paste was vertically compacted using an endodontic plugger size 4(Dentsply, Tulsa Dental Specialties, Tulsa, OK) till the entire canal was filled.

\section{TAP group}

The triple antibiotic paste was prepared using metronidazole (500-mg tablets [Flagyl $500 \mathrm{mg}$; Aventis, Cairo, Egypt]), ciprofloxacin (250-mg tablets [Ciprocin $250 \mathrm{mg}$; EPICO, Cairo, Egypt]) and doxycycline (100-mg capsules [Vibramycin; Pfizer, Cairo, Egypt]).The doxycycline capsule content was evacuated in a sterile mortar; a tablet of metronidazole and a tablet of ciprofloxacin were crushed and ground into homogenous powder in the same mortar using a pestle. Saline drops were added and mixed using the pestle until a creamy paste was achieved. The canal was filled with the paste using the same procedure as $\mathrm{Ca}(\mathrm{OH})_{2}$.

\section{Laser group;}

Intracanal irradiation was performed using a high power $980 \mathrm{~nm}$ diode laser (Fotona, EU) and set at a power of $7 \mathrm{~W}$ and $50-60 \mathrm{~Hz}$ frequency. It was divided into 3 sessions in which the total irrigation volume and time were standardized as $5 \mathrm{~mL}$ and 2 min but the irrigant was different. $2.5 \% \mathrm{NaOcl}, 17 \%$ EDTA and finally sterile saline were the irrigants used in each session respectively.

Using an oscillatory technique, the diode fiber ( $200 \mu \mathrm{m}$ fibre optic tip) was introduced $1 \mathrm{~mm}$ short of the apex and recessed in helicoidal movements at a speed of approximately $2 \mathrm{~mm} / \mathrm{sec}$ for 5 seconds, and repeated 8 times at intervals of 10 seconds. This laser activation procedure was repeated 3 times.

Control group; The samples were left empty.

All samples were incubatedfor a week at $37^{\circ} \mathrm{C}$ under humid conditions.

\section{Assessment of Antibacterial Activity}

After one week, the samples were irrigated with $20 \mathrm{ml}$ sterile saline solution to remove the root canal contents. Bacterial sampling and CFU counting protocols were used to determine the antimicrobial efficacy in each group (25).

Briefly, following all treatments, canals were filled with sterile $0.85 \%$ normal saline solution, $\# 40$ $\mathrm{H}$-file was introduced in the canal and churned for 1 minute, and then two \#40 sterile paper points were inserted into the canal to collect the bacteria for 1 minute. The paper points were transferred into $1 \mathrm{~mL}$ normal saline, and the process was repeated 3 times. All samples were vortexed for twenty seconds and 10 -fold dilutions were prepared in saline. Aliquots of $0.1 \mathrm{ml}$ were spread plated onto BHI agar plates, incubated at $37^{\circ} \mathrm{C}$ for 48 hours, and colony-forming units (CFU) per $1 \mathrm{~mL}$ were enumerated. 


\section{Statistical analysis}

$\mathrm{CFU} / \mathrm{mLvalues}$ were analysed by using ANOVA. Statistical analysis was performed using the SPSS program for Windows 10.0 (spss Inc., Chicago, IL, USA) $(\mathrm{P}<0.05)$.

\section{RESULTS:}

Results are demonstrated in (Table 1). The bacterial concentration in the control group had the highest number of microorganisms that revealed that bacteria survived the test period confirming the competence of the methodology.

For all experimental groups, there was a statistically significant reduction in the mean numbers of colony-forming units. However, none of them resulted in complete elimination of biofilm bacteria.

Overall, calcium hydroxide showed the weakest antimicrobial activity, and the tri antibiotic paste

and laser were higher. However, tri antibiotic paste and laser did not show statistical significance differences $(\mathrm{P}<.05)$.

SEM was done as an additional method to confirm the presence/absence of biofilm. Overall, a significant amount of bacteria revealed as biofilm was observed after 3 weeks of $\mathrm{E}$. faecalis inoculation covering the entire dentinal surface (Fig. 1). In $\mathrm{Ca}(\mathrm{OH})_{2}$ group, SEM images showed similar results when compared with the $\mathrm{CFU} / \mathrm{mL}$ data. Canals treated with Laser and TAP displayed a relevant bacteria-free surface

TABLE (1) Mean and standard deviations of $\mathrm{CFU}\left(\mathrm{x} 10^{4}\right) / \mathrm{mLin}$ all groups

\begin{tabular}{|c|c|c|c|c|}
\hline Group & Control & $\mathrm{Ca}(\mathrm{OH})_{2}$ & Laser & TAP \\
\hline CFU X10 & $10.28 \pm$ & $4.39 \pm$ & $0.55 \pm$ & $1.15 \pm$ \\
Mean \pm SD & $1.49^{\mathrm{a}}$ & $0.69^{\mathrm{b}}$ & $0.12^{\mathrm{c}}$ & $0.24^{\mathrm{c}}$ \\
\hline
\end{tabular}

Mean values followed by different lower case letters represent statistically significant differences $(P<.05)$.
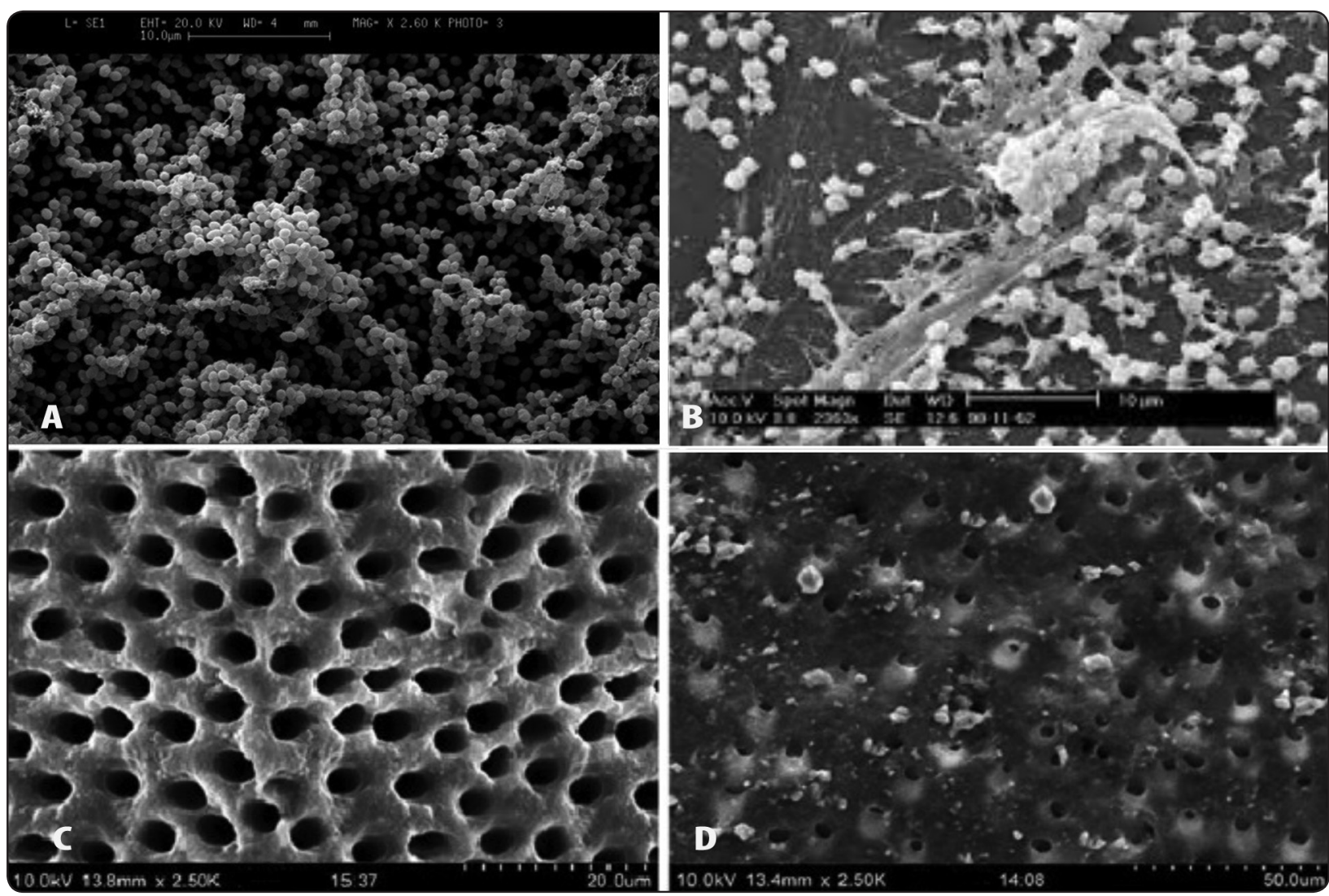

Fig. (1) SEM (X1500) showing : A. E. faecalis biofilm after 3 weeks of inoculation covering the entire dentinal surface. B: $\mathrm{Ca}(\mathrm{OH}) 2$ treated group with fewer adhering bacteria. $\mathrm{C}$ : laser treated sample and D: TAP treated sample. 


\section{DISCUSSION}

The aim of this study was addressed to assess the difference between laser-activated irrigation and the use of two different root canal medications in microbial reduction in infected root canals. Yet, under clinical conditions, those are only one of the steps to treat endodontic infections. The antimicrobial control stage also includes the use of irrigant solutions and mechanical instrumentation, which were both standardized.

E. faecalis was selected as the test species since its proved microbial role in persistent root canal infection. Human permanent teeth were used as the samples to mimic the clinical scenario. Studies evaluated the efficacy of a protocolin removing biofilms grown in wells ${ }^{(26)}$, on membrane filters ${ }^{(27)}$ and on dentin samples ${ }^{(28)}$. However, the bacterial colonization structure on dentine with dentinal tubules and considerable amount of unmineralized type I collagen that serves as an adhesion substrate to oral streptococci represents more logic way ${ }^{(29,30)}$.

Despite the high initial bacterial levels, all protocols were efficient in reducing significantly the levels of E.faecalis.

It had been proved that $\mathrm{Ca}(\mathrm{OH})_{2}$ is an effective intracanal medicament ${ }^{(17)}$ and it is the dressing most recommended for the treatment of infected root canals. Unfortunately, new concern has grown up about the limited antimicrobial efficiency of $\mathrm{Ca}(\mathrm{OH})_{2}$ against some microorganisms commonly found in infected root canals including E. faecalis that can withstand its high $\mathrm{pH}^{(31,32)}$. In the current study, $\mathrm{Ca}(\mathrm{OH})_{2}$ failed to effectively eliminate $\mathrm{E}$. faecalis from infected root canals in human teeth. The findings of the current study are consistent with recent researches ${ }^{(33-35)}$ but contradict the findings of others ${ }^{(36-38)}$. According to previous studies, the reasons for this were attributed to improper amount of hydroxyl ions reached after 1 week ${ }^{(39,40)}$, or the buffering action of dentin ${ }^{(14)}$.

Tri antibiotic paste use has been previously reported for the treatment of necrotic teeth with open apexes ${ }^{(41,42)}$. It was shown to have inhibitory effect on E.faecalis biofilm due to the components of this paste. It is made from metronidazole, which has a wide bactericidal effect against obligate anaerobes that are common in infected root canals. Certain bacteria are resistant to metronidazole; hence, ciprofloxacin and minocycline were added to achieve better antimicrobial action ${ }^{(19,43)}$. Our results showed a good ability of this paste to kill bacteria inside the biofilms in contrast to calcium hydroxide. However, this paste could not kill $100 \%$ of the bacteria inside the biofilm. This was in consistent with previous works in which the antimicrobial activity of these medications against oral bacteria, and their ability to sterilize infected dentin has been confirmed ${ }^{(19,20,44)}$. Unfortunately, Minocycline binds to calcium ions by chelation to form an insoluble complex causing tooth discoloration. Hence, TAP should be limited to the root canal ${ }^{(45,46)}$. In addition, an adequate antibiotic concentration that avoids toxicity to host stem cells has not been completely addressed yet ${ }^{(47)}$.

Consequently,there is a need to search for other antimicrobial method with comparable properties to the tested tri antibiotic paste deprived of its accompanied detrimental side effects.

Despite the proved efficacy of various lasers against microorganisms, studies in regards to laser's antimicrobial ability in root canal system are controversial. Our results showed reduction in CFU in laser group. This can be attributed to the direct delivery of laser energy by the used fine diameter optic fiber (200-320 $\mu \mathrm{m}$ that enabled effective delivery of laser light deeply into the root canal. The laser energy absorbed by the bacteria caused a photo-thermal interaction resulting in a bactericidal effect $^{(48)}$. Diode laser has high permeability and low interference with dentin, which allows the laser to be effective on microorganisms that have penetrated into the dentinal tubules ${ }^{(49)}$. Coluzzi ${ }^{(50)}$ reported that diode lasers have a depth of penetration per pulse that is 10,000 times greater than that of the Er:YAG laser and may act more deeply within the dentinal tubules. Gutknecht et al. ${ }^{(51)}$ reported that irradiation with a $980-\mathrm{nm}$ diode laser can eliminate bacteria 
that have migrated deep into the dentine (up to $500 \mu \mathrm{m}$ ), whereas chemical solutions can only reach $100 \mu \mathrm{m}$.

In this study, single straight root canals were selected to facilitate comparison of the bactericidal effect among different agitation techniques under a standard condition. However, in clinical practice, there are many teeth with curved root canals. On this occasion, the bactericidal effect of laser systems might be affected if the optical fiber could not easily advanced in the canals. Therefore, evaluation of the bactericidal effect of these systems in curved root canals and naturally infected root canals (ex vivo) would be performed in our future investigations.

In the present study, microorganisms were collected with sterile paper points from the root canal system as done in previous studies ${ }^{(24,25)}$. This sampling method has limitations because the paper points are only able to detect planktonic bacteria. Moreover, the paper points cannot access irregularities and other regions of the root canal system. Consequently, this approach might fail to harvest viable bacteria in biofilms and in some areas of the root canal system ${ }^{(52)}$. Thus, we accomplished the bacterial sampling by instrumenting the canal wall with sterile \#40 to remove dentine, permitting for a more predictable sampling.

Additionally, some cells of E. faecalis in biofilms can enter a stationary phase, which makes them undetectable with conventional culture methods ${ }^{(53)}$. Thus, the data obtained from CFU counts must be interpreted with caution ${ }^{(54)}$.

\section{CONCLUSION}

The diode laser systems, at the current settings had comparable properties to the tested tri antibiotic paste in reducing E. faecalis in the infected tooth model in vitro deprived of accompanied detrimental side effects of tri biotic paste. The search for laser applications in endodontics should however be continued and different laser wave lengths and settings should be examined.

\section{REFERENCES}

1. Lin J, Shen Y, Haapasalo M. A comparative study of biofilm removal with hand, rotary nickel-titanium, and self-adjusting file instrumentation using a novel in vitro biofilm model. J Endod2013;39: 658-63.

2. Haapasalo M, Endal U, Zandi H, Coil JM. Eradication of endodontic infection by Instrumentation and irrigation solutions. Endod Topics 2005;10:77-102

3. Ceri H, Olson ME, Stremick C, Read RR, Morck D, Buret A. The Calgary Biofilm Device: new technology for rapid determination of antibiotic susceptibilities of bacterial biofilms. J ClinMicrobiol 1999;37:1771-6.

4. Ricucci D, Siqueira JF Jr. Biofilms and apical periodontitis: study of prevalence and association with clinical and histopathologic findings. J Endod 2010;36:1277-88.

5. Stuart CH, Schwartz SA, Beeson TJ, Owatz CB. Enterococcus faecalis: its role in root canal treatment failure and current concepts in retreatment. J Endod2006;32: 93-8.

6. Gomes BPFA, Ferraz CCR, Vianna ME, Berber VB, Teixeira FB, Souza-Filho FJ. In vitro antimicrobial activity of several concentrations of sodium hypochlorite and chlorhexidine gluconate in the elimination of Enterococcus faecalis. IntEndod J 2001;34:424-8.

7. Gomes BPFA, Ferraz CCR, Garrido FD, Rosalen PL, Teixeira FB, Souza-Filho FJ. Microbial susceptibility to calcium hydroxide pastes and their vehicles. J Endod 2002;28:758-61.

8. Gomes BPFA, Ferraz CCR, Vianna ME, Rosalen PL, Zaia AA, Teixeira FB, Souza-Filho FJD. In vitro antimicrobial activity of calcium hydroxide pastes and their vehicles against selected microorganisms. Brazilian Dental Journal 2002;13, 155-61.

9. Menezes MM, Valera MC, Jorge AO, Koga-Ito CY, Camargo $\mathrm{CH}$, Mancini MN. In vitro evaluation of the effectiveness of irrigants and intra-canal medicaments on microorganisms within root canals. Int Endod J 2004;37:311-9.

10. Shuping GB, Ørstavik D, Sigurdsson A, Trope M. Reduction of intracanal bacteria using nickel-titanium rotary instrumentation and various medications. J Endod 2000;26:751-5.

11. Dalton BC, Ørstavik D, Phillips C, Pettiette M, Trope M. Bacterial reduction with nickel-titanium rotary instrumentation. J Endod 1998;24:763-7. 
12. McGurkin-Smith R, Trope M, Caplan D, Sigurdsson A. Reduction of intracanal bacteria using GT rotary instrumentation, $5.25 \% \mathrm{NaOCl}$, EDTA, and $\mathrm{Ca}(\mathrm{OH}) 2$. J Endod 2005;21:359-63

13. Sjögren U, Figdor D, Spangberg L, Sundqvist G. The antimicrobial effect of calcium hydroxide as a short-term intracanal dressing. Int Endod J 1991;24:119 -25.

14. Haapasalo HK, Siren EK, Waltimo TM, Orstvik T, Haapasalo MP. Inactivation of local root canal by dentine : an in vitro study. Int Endod J. 2000;33:126-31.

15. Kayaoglu G, Erten H, Ørstavik D. Growth at high pH increases Enterococcus faecalis adhesion to collagen. Int Endod J 2005; 38: 389-96.

16. Sahebi S, Moazami F, Abbott P. The effects of short-term calcium hydroxide application on the strength of dentine. Dent Traumatol 2010; 26: 43-6.

17. Siqueira J, Lopes H. Mechanisms of antimicrobial activity of calcium hydroxide: a critical review. IntEndod J 1999; 32: 361-9.

18. Mohammaddi Z. Antibiotics as an intracanal medicaments: a review. J Calif Dent Assoc 2009;37:98-108

19. Hoshino E, Kurihara-Ando N, Sato I, Kota K, Iwaku M. In-vitro antibacterial susceptibility of bacteria taken from infected root dentine to a mixture of ciprofloxacin, metronidazole and minocycline. Int Endod J 1996;29:12530 .

20. Sato I, Ando-Kurihara N, Kota K, Iwaku M, Hoshino E. Sterilization of infected root-canal dentine by topical application of a mixture of ciprofloxacin, metronidazole and minocycline in situ. IntEndod J 1996;29:118-24.

21. William W, Teixeira F, Levin L, Sigurdsson A, Trope M. Disinfection of immature teeth with a triple antibiotic paste. J Endod 2005;31:439-43.

22. De Souza EB, Cai S, Simionato MRL, Lage-Marques JL. High-power diode laser in the disinfection in depth of the root canal dentin. Oral Surgery, Oral Medicine, Oral Pathology, Oral Radiology, Endod 2008;106:e68-e72.

23. Meire MA, De Prijck K, Coenye T, Nelis HJ, De Moor RJG. Effectiveness of different laser systems to kill Enterococcus faecalis in aqueous suspension and in an infected tooth model. Int Endod J 2009;42:351-9.

24. Li Y, Sun K, Ye G, Liang Y, Pan H, Wang G, Zhao Y, Pan J, Zjang J, Fang J. Evaluation of Cold Plasma Treatment and
Safety in Disinfecting 3-week Root Canal Enterococcus faecalis Biofilm In Vitro. J Endod 2015;41:1325-30.

25. Miranda RG, Santos EB, Souto RM, Gusman H, Colombo AP. Ex vivo antimicrobial efficacy of the EndoVac system plus photodynamic therapy associated with calcium hydroxide against intracanal Enterococcus faecalis. Int Endod J 2013;46:499-505.

26. Dunavant TR, Regan JD, Glickman GN, Solomon ES, Honeyman AL. Comparative evaluation of endodontic irrigants against Enterococcus faecalis biofilms. J Endod 2006; 32:527-531

27. Spratt DA, Pratten J, Wilson M, Gulabivala K. An in vitro evaluation of the antimicrobial efficacy of irrigants on biofilms of root canal isolates. Int Endod J 2001;34:300-7.

28. Duggan JM, Sedgley CM. Biofilm Formation of Oral and Endodontic Enterococcus faecalis. J Endod 2007; 33:815-18

29. Dai X-F, Ten Cate AR, Limeback H. The extent and distribution of intratubular collagen fibrils in human dentine. Arch Oral Biol. 1991;36:775- 8.

30. Liu T, Gibbons RJ. Binding of streptococci of the mutans group to type 1 collagen associated with apatitic surfaces. Oral MicrobiolImmunol 1990;5:131-6

31. Evans M, Davies JK, Sundqvist G, Figdor D. Mechanisms involved in the resistance of Enterococcus faecalis to calcium hydroxide. Int Endod J 2002;35:221-8.

32. Flahaut S, Hartke A, Giard JC, Auffray Y. Alkaline stress response in Enterococcus faecalis: adaption, crossprotection, and changes in protein synthesis. Appl Environ Microbiol 1997;63:812-4.

33. Ørstavik D, Haapasalo M. Disinfection by endodontic irrigants and dressings of experimentally infected dentinal tubules. Endod Dent Traumatol 1990;6:142-9.

34. Schäfer E, Bössmann K. Antimicrobial effects of chloroxylenol and chlorhexidine in the treatment of infected root canals. DtschZahnärztl Z 2000;55:671-9

35. Sukawat C, Srisuwan T. A comparison of the antimicrobial efficacy of three calcium hydroxide formulations on human dentin infected with Enterococcus faecalis. J Endod 2002;28:102-4.

36. Schäfer E, Bössmann K. Antimicrobial effect of camphorated chloroxylenol (ED 84) in the treatment of infected root canals. J Endod 1999;25: 547-51. 
37. Estrela C, Bammann LL, Pimenta FC, Pécora JD. Control of microorganisms in vitro by calcium hydroxide pastes. Int Endod J 2001;34:341-5.

38. Lynne RE, Liewehr FR, West LA, Patton WR, Buxton TB, McPherson JC. In vitro antimicrobial activity of various medication preparations on $\mathrm{E}$. faecalis in root canal dentin. J Endod 2003;29:187-90

39. Distel JW, Hatton JF, Gillespie MJ. Biofilm formation in medicated root canals. J Endod 2002;28:689-93.

40. Nakajo K, Nakazawa F, Iwaku M, Hoshino E. Alkali-resistant bacteria in root canal systems. Oral MicrobiolImmunol 2004;19:390-4

41. Ding RY, Cheung GS, Chen J, Yin XZ, Wang QQ, Zhang CF. Pulp revascularization of immature teeth with apical periodontitis: a clinical study. J Endod 2009;35:745-9.

42. Jung IY, Lee SJ, Hargreaves KM. Biologically based treatment of immature permanent teeth with pulpal necrosis: a case series. J Endod 2008;34:876-87

43. Alam T, Nakazawa F, Uematsu H, Hoshino E. Susceptibility of Enterococcus feacalis to a combination of antibacterial drugs. (3 mix) in vitro. J Oral Biosci 2005;43:315-20.

44. Windley W 3rd, Teixeira F, Levin L, Sigurdsson A, Trope M. Disinfection of immature teeth with a triple antibiotic paste. J Endod 2005;31:439-43.

45. Jong HK, Yuram K, Shei SJ, Jeong WP, Jung IY. Tooth discoloration of immature permanent incisor associated with triantibiotic paste therapy. A case report. J Endod 2010;36:1086-91.

46. Kim JH, Kim Y, Shin SJ, Park JW, Jung IY. Tooth discoloration of immature permanent incisor associated with triple antibiotic therapy: a case report. J Endod 2010; 36:1086-91

47. Ruparel NTF, Ferraz C, Diogenes A. Direct effect of intracanal medicaments on survival of stem cells of the apical papilla. J Endod 2012;38:1372-5.

48. Bergmans L, Moisiadis P, Teughels W, Van Meerbeek B, Quirynen M, Lambrechts P. Bactericidal effect of Nd:YAG laser irradiation on some endodontic pathogens ex vivo. IntEndod J 2006;39:547-57.

49. Klim JD, Fox DB, Coluzzi DJ, Neckel CP, Swick MD. The diode laser in dentistry. Rev Wavelengths 2000;8:13-6.1.

50. Coluzzi DJ (2000) An overview of laser wavelengths used in dentistry. Dent Clin North Am 44:753-761

51. Gutknecht N, Franzen R, Schippers M, Lampert F (2004) Bactericidal effect of a 980-nm diode laser in the root canal wall dentin of bovine teeth. J Clin Laser Med Surg 22:9-13

52. Siqueira JF, Alves FR, Almeida BM, de Oliveira JCM, Rôças IN. Ability of chemomechanical preparation with either rotary instruments or self-adjusting file to disinfect oval-shaped root canals. J Endod 2010;36:1860-5.

53. Nakamura VC, Cai S, Candeiro GTDM, Ferrari PH, Caldeira CL, Gavini G. Ex vivo evaluation of the effects of several root canal preparation techniques and irrigation regimens on a mixed microbial infection. Int Endod $\mathrm{J}$ 2013;46:217-24

54. Liu H, Wei X, Ling J, Wang W, Huang X. Biofilm Formation Capability of Enterococcus faecalis Cells in Starvation Phase and Its Susceptibility to Sodium Hypochlorite. J Endod 2010;36:630-5. 